Research Article

\title{
Anthropological Perspective on Gender Disparities in India
}

\author{
Konduru Delliswararao*
}

Dept of Anthropology, Pondicherry University, Pondicherry-605014, India

\begin{tabular}{|c|c|}
\hline Article Information & Abstract \\
\hline $\begin{array}{l}\text { Received: } 28 \text { April } 2021 \\
\text { Revised version received: } 19 \text { July } 2021 \\
\text { Accepted: } 21 \text { July } 2021 \\
\text { Published: } 29 \text { July } 2021 \\
\text { Cite this article as: } \\
\text { K. Delliswararao (2021) Int. J. Soc. Sc. Manage. } \\
\text { 8(3): 416-425. DOI: 10.3126/ijssm.v8i3.36526 } \\
\text { *Corresponding author } \\
\text { Konduru Delliswararao, } \\
\text { Dept of Anthropology, Pondicherry University, } \\
\text { Pondicherry-605014, India } \\
\text { Email: delli.swarao@gmail.com }\end{array}$ & $\begin{array}{l}\text { Gender is a social term; it is using for both male and female. But due to the } \\
\text { inequality and discrimination, the gender term is more adopted only to female or } \\
\text { women discrimination. In developing countries like India, gender inequality, } \\
\text { discrimination is very high due to so many factors, such as economical factors, } \\
\text { cultural factors and others. India is } 140^{\text {th }} \text { Rank, out of } 156 \text { countries in world's } \\
\text { gender gap index. It is showing that India's performance in gender equality. Not } \\
\text { only a govt, every individual in the society are responsible for the gender inequality } \\
\text { in India. When comparing with other nations, India's ranking is lower than African } \\
\text { countries. The main objective of the present paper explains the socio-cultural, } \\
\text { economical, and other factors in various sectors in Pondicherry related to gender } \\
\text { equality. Another aim of the study is to understanding the women development in } \\
\text { a holistic manner. The methodology of the paper is Mixed Method of research. }\end{array}$ \\
\hline $\begin{array}{l}\text { Peer reviewed under authority of IJSSM } \\
\text { (C) } 2021 \text { IJSSM, Permits unrestricted use under the } \\
\text { CC-By-NC license. }\end{array}$ & \\
\hline $\begin{array}{l}\text { OPEN ACCESS } \\
\text { This is an open access article \& it is licensed under a } \\
\text { Creative Commons Attribution Non-Commercial 4.0 } \\
\text { International } \\
\text { (https://creativecommons.org/licenses/by-nc/4.0/) }\end{array}$ & \\
\hline nination; Ine & \\
\hline
\end{tabular}

\section{Introduction}

According to the oxford dictionary, gender means of the two sexes (male and female). Especially, when considering the social and cultural differences rather than biological ones. The term is also using more broadly to denote a range of identities that do not correspond to established ideas of male and female. Gender is a social term; it is using for both male and female. But due to the inequality and discrimination, the gender term is more adopted to female or women discrimination. The United Nations charter principles number four describes the women equity and equality of women, women empowerment, and elimination of all kinds of violence against women (Betata, 2007; Bhatt and Ahmad, 2015). Moreover, it's ensuring the women ability to control their own fertility, because, these are the corner stone of the women and population development. This principle also discusses the equal participation of women in civil, socio-cultural, political and economic life at community, national and international level. The United Nations sustainable development goals number three discuss about good health and wellbeing, five explains the 
gender equality, goal number seventeen said about partnerships for the goals (https://sdgs.uno.org/2015/pdf/). The Indian constitution is giving equal rights and responsibilities to every citizen through the preamble, fundamental rights and duties. But till to the date, the govt has not succeeded in gender equality. The problem is not only in the govt, but it is also in the society. Every individual is responsible for gender inequality. When the people and community mindset are not changed, until then gender inequality also not changed. According to the United Nations Development Programme (UNDP); India has got the $123^{\text {rd }}$ Rank, with 0.488 score in the gender inequality index-2020

(http://hdr.undp.org/en/countries/profiles/IND/Pdf).

According to the eminent scholar's women play three types of roles, such as Productive role, Re-Productive role, Social Productive role. The truth is $1 / 4$ of women are working, a 2/3 of work in anywhere and in any sector (Satyavrat, 2017). This much roles and responsibilities are playing a woman, but still, she is ignoring everywhere. In developing countries like India, gender inequality and gender discrimination are very high due to so many factors. The researcher has divided the factors into three categories, such as Socio-Cultural Factors, Economic factors, other factors (Klasen, 2006).

\section{Socio-Cultural Inequalities}

Family and relative's pressure, other cultural influences like joint families, dependent children, elders caring responsibilities, lack of decision-making power, marriage and mobility. Patriarchal society; male education is the first preference, early child marriages, women discrimination at home and in the workplace. Psychological stress due to the dual works, dual work means domestic (household) work, and professional work.

\section{Economic Inequalities}

Economic inequalities like discrimination in work participation, wage differences, access denied crediting, financial constraints. Educational inequalities such as discrimination in schooling years, lack of skills, low literacy levels, lack of choice based education. Occupational inequalities like lack of right opportunities, low investment on girls education in developing countries like India, financial dependency, part-time jobs and work at home facilities are very low in India, low sex ratio, indebtedness and family financial crisis, lack of policy support, women labour are more in agriculture, and the informal and unorganised sector, lack of human capital, invisibility and undercount of women work, job matching difficulties are severe in women, exploitation, bonded labour, the rural women are more focused on working as agricultural labour, and working as a labour in bricks industry and beddi industry, the tobacco industry, jute and sugar mills and so on. Some of the women are working as tailors in their villages, and it's like self-employment they do the embroidery works and switching the clothes and so forth (Wiklander, 2010).

\section{Other Inequalities}

Other inequalities like Health inequalities and Survival inequalities, political disparities. Other interventions to I.C.T. for women in developing countries like India, is exclusion from technology, limited availability of free time, social norms favouring men, lack of transportation facilities, I.T. Industry all are locating in urban areas and megacities only. Institutional barriers, access and control \& effective use, education, training and skill development, content and language, pornography, trafficking, violence against women and censorship, gender segregation in employment, indigenous knowledge and Intellectual property rights, I.C.T. Policy and governance, absence from decision making structures, privacy, security and surveillance, freedom to communicate, women place-based activism and virtual politics. Skill gaps like technical skills, soft skills and personal skills.

Gender equality and empowerment of women has been the cornerstone of developmental policies of many countries across the globe. The recent Sustainable Development goals 2015 recognise the centrality of women empowerment and gender equality for the elimination of poverty and hunger and the achievement of genuinely sustainable development. The gender gap in labour force participation rates and unemployment rates are persistent features of global labour markets. These issues need to be addressing to ensure gender equity in the labour market, which requires concerted efforts both at the academic and policy level. Labour market gender gaps are more pronounced in developing countries, and often exacerbated by gendered patterns in occupational segregation with the majority of women work is concentrated in a narrow range of sectors that remain vulnerable and insecure. These workers are mostly engaged in informal employment as domestic workers, self-employed, casual workers, piece-rated workers, home-based workers and migrant's workers with poor skills, less earnings and low productivity (Banerjee and De, 2018).

Further, the gender pays gap and wage differentials remain a serious concern that needs to be addressing. Apart from this, the contribution of women to the national economy is still subject to more under-reporting and misrepresentation in comparison to the assistance of men. The statistics available are partial and contribute to maintaining a distorted perception of the nature of a country economy and its human resources thereby perpetuating a vicious circle of inequality between men and women caused by wrong perceptions, policies and programmes. Given the challenges women are facing in the labour market, promoting gender equality and empowering women is fundamental for achieving the new targets of full productive employment 
and social inclusion to mark the global goals on sustainable development. For achieving inclusive growth and substantive equality, awareness on policies, skill development, capacity building, social dialogue and empowerment through training and research would be some of the main activities (https://vvgnli.gov.in/research/centregender-and-labour-studies/).

As per the result of labour force survey on employment and unemployment conducted in 2011-12 by National Sample Survey Office (N.S.S.O.), Ministry of Statistics and Programme Implementation, the number of estimated employed persons in 2011-12 on usual status basis were 47.41 crores, of which $82.7 \%$ of the workforce (39.14 crores persons) was in unorganised sector ${ }^{3}$. According to some official sources, in India, the total workforce is 460 million. In that 16 per cent of the workforce is are in the organised sector. Remaining 84 per cent of the workforce is working, in the unorganised sector. The Informal sector employees are 7 per cent; it means in India, total workforce of both unorganised and informal sector is more than 91 per cent. In India, the present total workforce is, 25 per cent of the total Indian population. As per N.S.S.O (2014-15), 45 per cent of women and 57 per cent of the male population are working in agriculture and allied sector in India (https://labour.gov.in/sites/default/files/Report/20/vol/204/ 2018/final.pdf/). According to the N.S.S.O in India, only 13 per cent of land holds on women name, and 4 to 5 per cent of women only get social security benefits in India (http://mospi.nic.in/sites/default/files/publication_reports/I ndia_in_figures-2018_rev.pdf/). As per census 2011 in India, the total women population percentage is 49 per cent approximately, and the literacy rate is 45 per cent only. At the same time, in the workforce, the women percentage is only 25 percent (http//:www.censusofIndia.nic.in/census2011/.pdf/ accessed on 20/July/2020). In India, 21 per cent of the population are under the "Neither in Education, Employment Not in Training - (NEET)" in that 65 per cent are women only. These statistics are showing that a clear picture of women discrimination and gender inequalities in India (http://www.oecd.org/social/genderdevelopment/47561694.pdf/).

The Table 1 is explained the India gender gap index and gender inequalities rank worldwide. It shows that women are living in India.

Table 2 explains India worldwide Rank on women knowledge on Information and Communication Technology (I.C.T).

The Table 3 explains the different kinds of women empowerment and its key points.

Table 1: India Gender Gap Ranking table

\begin{tabular}{|l|l|l|l|}
\hline Indicator & India World Rank & Source & Year \\
\hline Gender Gap Index (G.G.I) & $112 / 153$ & WEF & 2019 \\
\hline Gender Gap Index & $108 / 149$ & WEF & 2018 \\
\hline Gender Gap Index & $108 / 144$ & W.E.F & 2017 \\
\hline Gender Gap Index & $87 / 144$ & W.E.F & 2016 \\
\hline Gender Gap Index & $101 / 136$ & W.E.F & 2013 \\
\hline (G.I.I) Gender Inequality Rank & $132 / 148$ & U.N.D.P & 2012 \\
\hline (S.I.G.I) Social Institutions \& Gender Index & $56 / 86$ & O.C.E.D & 2012 \\
& & & \\
\hline
\end{tabular}

Table 2: India's I.C.T. Development Index (I.D.I.) Ranks

\begin{tabular}{|l|l|l|l|}
\hline Year & India's worldwide Rank & India's Asia - pacific Rank & India's score \\
\hline 2015 & $135 / 175$ & 25 & 2.50 \\
\hline 2016 & $138 / 176$ & 26 & 2.69 \\
\hline 2017 & $134 / 176$ & 25 & 3.03 \\
\hline \multicolumn{2}{|l}{ Source: I.T.U. - 2015, I.T.U. - 2016, I.T.U. - 2017 } \\
\hline
\end{tabular}


Table 3: Types of Women Empowerments and its Details

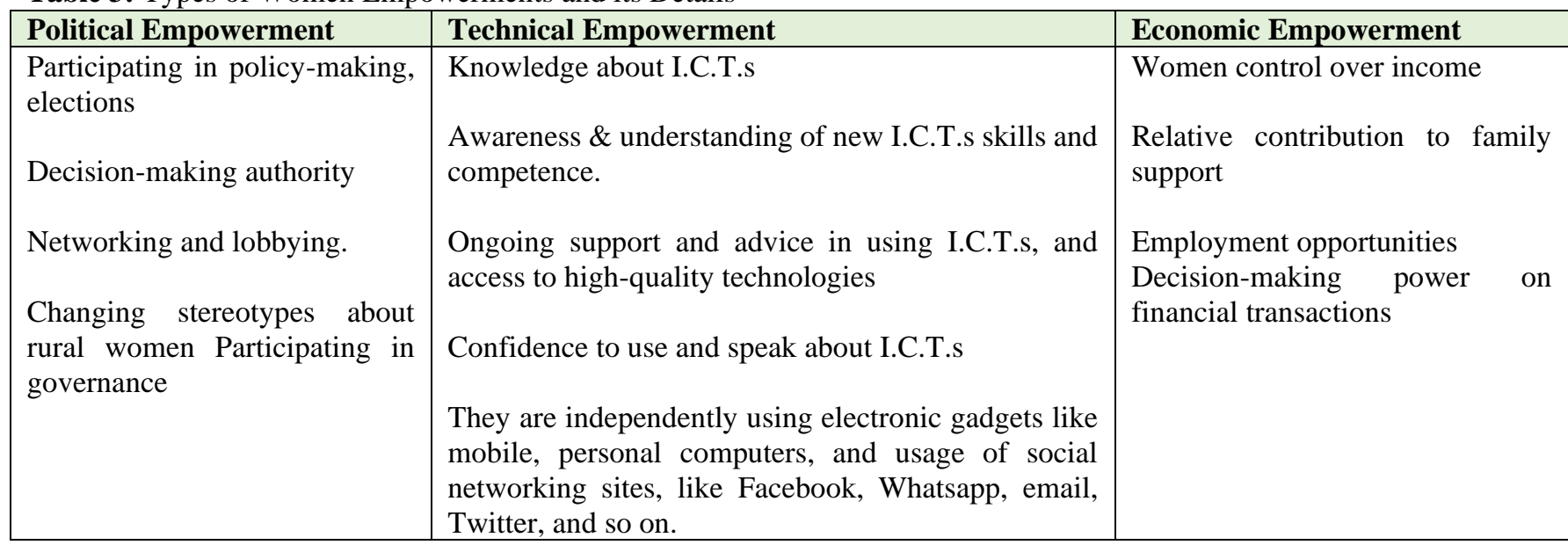

Source: Huyer and Westholm, 2007.

\section{Concepts of Labour and Women}

\section{Unorganised Sector}

According to "National Commission for Enterprises of India", the unorganised sector means "consisting of all unincorporated private enterprises owned by individuals or households engaged in the sale or production of goods and services operated on a sole proprietary or partnership basis, and with less than ten workers, it is called as an unorganised sector" (https://msme.gov.in/national-commissionenterprises-un-organised-sectornceus/).

\section{Organized Sector}

According to "National Commission for Enterprises of India"; Organized Sector means, "the sector in which the employment terms are fixed and followed the owners or proprietors, and employees have assured to work and working hours, salaries, other benefits. And the organisation is more than ten employees in enterprises or sector is called as an organised sector" (https://msme.gov.in/national-commission-enterprises-unorganised-sectornceus/).

\section{Labour Force}

Labour force $=$ working force + non-working force

It means both of the unemployed population and employed population (working force) total is calling as a labour force (https://labour.gov.in/sites/default/files/Report/20/vol/204/ 2018/final.pdf/).

\section{Working Force}

According to the "Indian Labour Institute", the 15-59 years of age group population is called as a working force. It means who have under the age group of 15-59 years and both physically and mentally able to work, they are calling as a working force. According to the labour ministry sources in India, the present total workforce is 25 per cent of total Indian population.

\section{Formal Sector}

The sector or industry which is gives social security benefits like Provident Fund (P.F), Employees State Insurance (E.S.I.), and other benefits, to their employees. Such enterprises group or sector is calling as a formal sector.

\section{Informal Sector and Contract Employment}

The sector, which one is not, provides any social security benefits like P.F, E.S.I.C, and other benefits to their employees. Such enterprises group or sector is calling as Informal Sector. Informal employment in the formal sector is calling as a contract employment

\section{Research Methodology}

Methodology of this study is mixed-method research; it means, both quantitative and qualitative of study. The present study has, consists of both primary and secondary data. The primary data is collecting through quantitative and qualitative methods. The researcher is collected a quantitative data, through interview schedules. He used qualitative tools like participant observation on the field, and two focus group discussions (F.G. D's). The sample size of the research is 40; the area of study is Pondicherry. The primary data is collected from December / 2018 to January / 2019. The analysis of information is executed with the help of MS-Excel, and Statistical Package of Social Sciences (S.P.S.S.). The secondary data is collected from various official and non-official sources as given in the reference list.

\section{Results and Discussion}

Table 4, explains that total number of informants and age wise distribution. Most of the informants are between the ages of 30-39 years, which is 16 informants under this category. Whereas 13 informants are belonging to 40-49 age group, and 7 informants are coming under the 20-29 years of age. Finally, 4 informants are having highest age, they are belonging to 50-59 age group. The average age of the informants is 39.5 years. 
Table 5 shows that the, distribution of the informants' marital status. Out of the total informants, 31 informants are married. Remaining, 9 informants are un-married.

Table 6 reveals that the distribution of the number of children to the informants. According to research, single child mothers are 12 members, and two children's mothers are 11 members. Twenty percent, which means eight members, have three children. Out of the 40 members, nine members don't have any children.
Table 7 describes that the distribution of informant's educational level. Out of the 40 informants, six informants are Illiterates. Three informants have completed Primary Education, and ten informants are completed their Secondary Education. 7.5 per cent of informants are having Graduation Qualification, whereas 17 members are completed their master's degree/engineering.

Table 4: Distribution of Informants Age Group

\begin{tabular}{|l|l|l|l|l|}
\hline \multicolumn{2}{|l|}{ Age Group } & Frequency & Valid Percent & Cumulative Percent \\
\hline Valid & $20-29$ & 7 & 17.5 & 17.5 \\
\cline { 2 - 6 } & $30-39$ & 16 & 40.0 & 57.5 \\
\cline { 2 - 6 } & $40-49$ & 13 & 32.5 & 90.0 \\
\cline { 2 - 5 } & $50-59$ & 4 & 10.0 & 100.0 \\
\cline { 2 - 5 } & Total & 40 & 100.0 & \\
\hline
\end{tabular}

Table 5: Distribution of Informants Marital Status

\begin{tabular}{|l|l|l|l|l|}
\hline \multicolumn{2}{|l|}{ Marital Status } & Frequency & Valid Percent & Cumulative Percent \\
\hline Valid & Married & 31 & 77.5 & 77.5 \\
\cline { 2 - 5 } & Un-Married & 9 & 22.5 & 100.0 \\
\cline { 2 - 5 } & Total & 40 & 100.0 & \\
\hline
\end{tabular}

Table 6: Distribution of No of Children to the Informants

\begin{tabular}{|l|l|l|l|l|}
\hline \multicolumn{2}{|l|}{ No of Children } & Frequency & Valid Percent & Cumulative Percent \\
\hline Valid & 1 Children & 12 & 30.0 & 30.0 \\
\cline { 2 - 5 } & 2 Children & 11 & 27.5 & 57.5 \\
\cline { 2 - 5 } & 3 Children & 8 & 20.0 & 77.5 \\
\cline { 2 - 5 } & No Children & 9 & 22.5 & 100.0 \\
\cline { 2 - 5 } & Total & 40 & 100.0 & \\
\hline
\end{tabular}

Table 7: Distribution of Informants Education level

\begin{tabular}{|l|l|l|l|l|}
\hline \multicolumn{2}{|c|}{ Education Level } & Frequency & Valid Percent & Cumulative Percent \\
\hline \multirow{6}{*}{ Valid } & Illiterate & 7 & 17.5 & 17.5 \\
\cline { 2 - 5 } & Primary & 3 & 7.5 & 25.0 \\
\cline { 2 - 5 } & Secondary & 10 & 25.0 & 50.0 \\
\cline { 2 - 5 } & Graduation & 3 & 7.5 & 57.5 \\
\cline { 2 - 5 } & Master Degrees / Engineering & 17 & 42.5 & 100.0 \\
\cline { 2 - 5 } & Total & 40 & 100.0 & \\
\hline
\end{tabular}


Table 8 explains the distribution of informants Occupation. According to the research, ten members are working as a fisherwoman. Twenty-five per cent of informants, which mean ten members, are working in the food \& beverages industry. Five members are having their own business; out of the 40 members, 15 were working as a teacher.

Table 9 shows that the distribution of informants Economical Status. As per research, 50 per cent of informants are coming under Below Poverty Line (BPL). Remaining 50 per cent of informants, which means 20 informants were Above Poverty Line (A.P.L.).

Table 10 shows that the distribution of informant's income level. Out of the total informants, 20 member's incomes below is 10000 rupees only. Seven members were, earning between 21000-30000 rupees. However, ten members monthly income is between the $31000-40000$ rupees. Only three members are earning between the 41000-50000 rupees, as a monthly income.

Table 11 discusses the distribution of discrimination faced by informants at home. Sixteen members reveal that still, they are facing discrimination frequently at home. Out of the 40 members; 15 members are expressed, they are facing discrimination rarely. Only nine members said they don't have to face any discrimination at home.

Table 8: Distribution of Informants Occupation

\begin{tabular}{|l|l|l|l|l|}
\hline \multicolumn{2}{|c|}{ Occupation } & Frequency & Valid Percent & Cumulative Percent \\
\hline Valid & Fishing & 10 & 25.0 & 25.0 \\
\cline { 2 - 5 } & Food \& Beverages & 10 & 25.0 & 50.0 \\
\cline { 2 - 5 } & Business & 5 & 12.5 & 62.5 \\
\cline { 2 - 5 } & Teacher & 15 & 37.5 & 100.0 \\
\cline { 2 - 5 } & Total & 40 & 100.0 & \\
\hline
\end{tabular}

Table 9: Distribution of Informants Economical Status

\begin{tabular}{|l|l|l|l|l|}
\hline \multicolumn{2}{|c|}{ Economic Status } & Frequency & Valid Percent & $\begin{array}{l}\text { Cumulative } \\
\text { Percent }\end{array}$ \\
\hline Valid & BPL & 20 & 50.0 & 50.0 \\
\cline { 2 - 5 } & APL & 20 & 50.0 & 100.0 \\
\cline { 2 - 5 } & Total & 40 & 100.0 & \\
\hline
\end{tabular}

Table 10: Distribution of Informants Monthly Income Level

\begin{tabular}{|l|l|l|l|l|}
\hline \multicolumn{2}{|c|}{ Income Group } & Frequency & Valid Percent & Cumulative Percent \\
\hline Valid & $1000-10000$ & 20 & 50.0 & 50.0 \\
\cline { 2 - 5 } & $21000-30000$ & 7 & 17.5 & 67.5 \\
\cline { 2 - 5 } & $31000-40000$ & 10 & 25.0 & 92.5 \\
\cline { 2 - 5 } & $41000-50000$ & 3 & 7.5 & 100.0 \\
\cline { 2 - 5 } & Total & 40 & 100.0 & \\
\hline
\end{tabular}

Table 11: Distribution of Discrimination Faced by Informants at Home

\begin{tabular}{|l|l|l|l|l|}
\hline \multicolumn{2}{|c|}{ Discrimination at Home } & Frequency & Valid Percent & Cumulative Percent \\
\hline Valid & YES, frequently & 16 & 40.0 & 40.0 \\
\cline { 2 - 5 } & YES, rarely & 15 & 37.5 & 77.5 \\
\cline { 2 - 5 } & No Discrimination & 9 & 22.5 & 100.0 \\
\cline { 2 - 5 } & Total & 40 & 100.0 & \\
\hline
\end{tabular}


Table 12 explains that, the distribution of discrimination faced by informants at work and in community. Sixteen members are told that regularly they are facing discrimination at the workplace and in society. These all are working in the market and unorganised sector. Nine members describe that they are having an experience of discrimination at working place as well as in the community. Out of the 40 members; 47.5 per cent of informants, which means 19 members are expressed, they not facing any discrimination at work and in community. Those 19 informants are working in formal sector, as well as well educated.
Table 13 reveals that the distribution of the type of discrimination faced by informants. 82.5 per cent of members; which means 33 members indicate that they are facing discriminatn in the form of "Oral Abuse/ Scolding/ Humiliation" everywhere. Out of the 40 members; 7 members are told that they are not facing any form of discrimination.

Table 14 explains the Pearson correlation between the variables and its values, and comparison with Pearson correlation standard value. The Pearson correlation standard value is between the -1 to +1 . The above table shows that the correlation between the variables has a positive correlation.

Table 12: Distribution of Discrimination Faced by Informants at Work \& in Community

\begin{tabular}{|l|l|l|l|l|}
\hline \multicolumn{2}{|l|}{ Discrimination at Work \& in Community } & Frequency & Valid Percent & Cumulative Percent \\
\hline Valid & Yes, frequently & 12 & 30.0 & 30.0 \\
\cline { 2 - 5 } & Yes, rarely & 9 & 22.5 & 52.5 \\
\cline { 2 - 5 } & No Discrimination & 19 & 47.5 & 100.0 \\
\cline { 2 - 5 } & Total & 40 & 100.0 & \\
\hline
\end{tabular}

Table 13: Distribution of Type of Discrimination Faced by Informants

\begin{tabular}{|l|l|l|l|l|}
\hline $\begin{array}{l}\text { Which type of discrimination Faced by } \\
\text { Informants }\end{array}$ & Frequency & $\begin{array}{l}\text { Valid } \\
\text { Percent }\end{array}$ & $\begin{array}{l}\text { Cumulative } \\
\text { Percent }\end{array}$ \\
\hline Valid & Oral Abuse / Scolding / Humiliation & 33 & 82.5 & 82.5 \\
\cline { 2 - 5 } & No Abuse & 7 & 17.5 & 100.0 \\
\cline { 2 - 5 } & Total & 40 & 100.0 & \\
\hline
\end{tabular}

Table 14: Distribution of Correlation Between the Variables \&Values of the Informants

\begin{tabular}{|l|c|c|}
\hline Pearson Correlation Between the Variables & Correlation value & Standard value \\
\hline Income \& Discrimination at home & 0.64 & \\
\hline Income \& Discrimination at office & 0.78 & \multirow{2}{*}{ Between the +1 to -1} \\
\hline Income \& type of Discrimination & $\pm 1)$ \\
\hline Income \& Occupation & 0.85 & 0.85 \\
\hline Income \& Educational level & 0.96 & \\
\hline Education \& Occupation & 0.95 & 0.8 \\
\hline Income \& Economic status & 0.85 \\
\hline Education \& Discrimination at home & \\
\hline Education \& Discrimination at office & \\
\hline
\end{tabular}


According to the research, the fishing community women are doing their business from past twenty to twenty-five years onwards. They are told that it is a traditional and community business. The fishing community informants are not well educated; but they handle all market transactions like purchases the fishes from boat vendors, and selling the fishes to customers. They have well knowledge on preservation technologies of fishes. The older women in the fishing community have played a key role in fish auction. These fishing women are playing dual roles in their daily life. Such as a family member they are doing, all domestic (household) works at home. After that, they are coming to the fish market for their professional work. The fishing community women are facing discrimination regularly, at home and in the community. But now, due to family members support, they were working smoothly in the market. When the fisherwomen went to market, the family members and children are doing household activities. These fishing women are not willing to transfer this field to their children, due to indebtedness and social discrimination and non-profitable due to climatic changes and increase in fuel prices.

As per research, ten informants are working in the food and beverage industry, they were working for the past ten years. In those ten informants, some of them completed their secondary level education, due to the financial crunches they do not go to higher studies. Due to that, they are starting their career in the food and beverage industry. Those informants are coming from the different socialeconomic background, and they are facing so many difficulties like social discrimination from the community. As per informants; nowadays, they are working in a safe and secure environment. Moreover, their families are supporting very well. Even the management of the food and beverage industry is also helping women employees. The management is providing very healthy working conditions in the industry, and providing transportation facilities, shift duties and salary advances etc. According to the informants, they are not interested in changing their present job, due to the facilities provides by management.

The researcher also meets the five women entrepreneurs, as a part of the study. Those informants are running different types of business, as well as manufacturing units. In those informants one of the informants is run their family business successfully, all the informants were started their business with small investments only. At the early days of business, those informants have all faced the humiliation, discrimination from their own family relatives and elders of the family. According to some informants, they are faced with gender discrimination at the time of getting license and loan approvals in govt organisations as well as in banks. But they have strongly faced their challenges, and win their fields. Now those informants are role models, to upcoming women entrepreneurs into respective fields. Those entrepreneurs have recruited eighty per cent of women, as their staff. All informants are told that without their family members support those achievements do not come to existence. As per informants, they are creating the working, friendly environment in their business. In their business the women staffs gets an equal salary with men, sometimes it is more than men salaries. Moreover, the informants are sanctions a paid leaves to women during their health issues. According to the informants, since 2005 onwards the progressive changes are happening in policy-making and implementation of women development.

According to research, 15 informants are completed their Master's Degree. Some of them are completed, their Doctoral Degree $(\mathrm{PhD})$ in respective subjects. Out of fifteen informants, four informants are working as an Assistant Professor. Remaining informants are working as a teacher, research associates in the public and private sector. As per informants; during their education they all are faced discrimination and humiliation like "what is the necessity the higher education to girls", from the relatives, as well as the community. But with the help of parents and family members support, they are succeeding in their career achievements. As per informants; due to their family financial crisis, they are chosen teaching as a career on early stages. But now, they are enjoying their teaching profession.

\section{Findings}

The researcher finds the different kinds of inequalities in his research, and they are as follows.

All informants have faced the community pressure and family pressure at the initial stage. But with the help of families' members support, they overcome social discrimination.

All informants are handling the other socio-cultural responsibilities like family responsibilities, dependent children, and elders caring responsibilities.

Some of the informants have to face the lack of decisionmaking power till to date. Marriage and mobility is another problem for women from getting good opportunities.

Some of the informants said that they faced the problem of male education is the first preference in their families too. They all are told that they are faced with discrimination at home and in the work place.

All informants are told that they have psychological stress due to dual works; the dual works means domestic (household) work and professional work.

Informants from formal sector like food and beverage industry are told that they faced an economic inequality like discrimination in work participation, wage differences on initial career stage. 
The women entrepreneurs are told that they all are faced a problem of access denied to credit from banks and govt organisations on the early stages of business.

Informants from formal sector and food and beverage industry workers have faced an Educational Inequalities, such as discrimination in schooling years, lack of skills, and lack of choice-based education.

Low investment in girl's education in developing countries like India is also another setback.

Occupational Inequalities like lack of right opportunities, part-time jobs and work at home facilities are very low in India,

Indebtedness and family financial crisis is one of most factors for women to not get the right opportunities. Lack of policy support is one of the main obstacles from the government.

The rural women are more focused on working as agricultural labour, a labourer in bricks industry, bedding industry and tobacco industry, jute and sugar mills so on.

Other interventions, like I.C.T. for women in developing countries like India, is exclusion from technology, lack of transportation facilities, I.T. Industry all are located in urban areas and megacities only. Lack of women-centred I.C.T. Policy's and governance, absence from decision making structures, women place-based activism and virtual politics. Skill gaps like technical skills, soft skills and personal skills are some of the main obstacles to educated women to getting good opportunities.

Other inequalities like Health Inequalities, political inequalities, social norms favouring men, training and skill development, human and child trafficking, gender segregation in employment, indigenous knowledge, security and surveillance, faced by fisherwomen in the community.

\section{Measures}

The following measures should be need to women development, especially working women. Such as, Collaborative work with N.G.O.'s for working women welfare. Financial independence is the key factor to women empowerment, and its helps to inclusive growth of the Indian economy. Govts should focus on financial freedom to women, minimum wage scale is essential for every sector. Moreover; controlling of wage disparities, between rural and urban woman wages is necessary. Providing facilities to Rejoin or Re-start old jobs is vital to working people, especially women. Good continuing education facilities or flexible education facilities are more useful to working women, for getting higher qualifications and career prospective. The other measures are divided into two categories, like demand side measures and supply side measures (Charmes and Wieringa, 2003).
Demand-side measures like; Women centred Micro, Small, Medium Enterprises (M.S.M.E.'s) policies are needed in India and as well as efficient labour laws. Women centred health policies and frameworks, is very important to women growth.

Supply-side measures like; National Skill Development Corporations, Skill India Programmes, S.A.N.K.A.L.P. Programme and other related programmes is needed for women for developing the skill sets.

The Governments also should be supported financially and technically, to the employers to women equality and their welfare. For example, Govts should provide reimbursement to the employers, who have paid the maternity leaves to women employees and labours with full salaries. Governments should take responsibilities of gender equality policies, and its effective implementation. Employers should give an assurance to women, to equal access to employment and wages or salaries equally with men. Work at home, placement at rural areas is another option to gender equality in work. Ownership of land and partnership on firms and other management positions to women is giving an opportunity to economic independence and decisionmaking power to women. Social networks are played a key role to women empowerment and in the job market also. The social networks are also giving safety and security to the women, when she was going outside alone, or handle any critical situations. The social networking applications are passing the information to relatives, friends, colleagues, within a fraction of seconds. Especially in the information technology sector, social networks play a magnificent role in the women job market. Social networks are very important, because it has reciprocity, safe and secure, information drain, creates opportunities, use for own benefits, less leisure time to interact with neighbours and relatives in a short period, and so forth.

\section{Conclusion}

Big fact is that; after 74 years of independence also, the women has still existing with the primary obstacles, for their own development. But, gender inequality and discrimination are social illness; we are not finding an immediate solution. Moreover; it is continuing from the ancient period, and it is correlating with socio-cultural issues. Due to that; the scholars, researchers, as well as policymakers, find out the solution in the holistic approach. Then only at least future generations enjoy the gender equity and equality, it helps to gender mainstreaming in to the society. Even society also needs to take some essential measures, like educate both the male and female, financial independence to women and so forth. It is more important to women empowerment and inclusive growth. At the same time, further research should be empathy, and it should be touching the grass root level of problems. 


\section{Conflicts of Interest}

None

\section{References}

Banerjee S and De N (2018) India's Informal Employment in the Era of Globalisation: Trend and Challenges. I.O.S.R. Journal of Business and Management (IOSR-JBM) 20(4): 12-20.

Betata HC (2007) what is missing in measures of women's empowerment. Journal of Human Development 2: 221241.

Bhatt and Rouf A (2015) Role of Education in the Empowerment of Women in India. Journal of Education and Practice 6(10): 188-191.

Charmes J and Wieringa S (2003) Measuring Women's Empowerment, An Assessment of the Gender- Related Development Index and the Gender Empowerment Measure. Journal of Human Development 4: 419-435.

Huyer S and Westholm G. (2007) Gender indicators in science, engineering and technology: an information toolkit. Unesco;.

Klasen S (2006) UNDP's Gender-Related Measures: Some Conceptual Problems and Possible Solutions. Journal of Human Development 7(2): 243-274.

Retrieved from http://www.censusofIndia.nic.in / census2011/.pdf/ accessed on 20/July/2020

Retrieved from https://gender-summit.com/gs8-speakers/830huyer.pdf/ accessed on 30/11/2020

Retrieved from https://msme.gov.in/national-commissionenterprises-un-organised-sectornceus/ accessed on $06 / 12 / 2020$

Retrieved from https://www.itu.int/en/Pages/default.aspx I accessed on 10/12/2020

Retrieved from Jagori and U.N. Women (2010), Report on the Baseline Survey. Available at: http://jagori.org/wpcontent/uploads/2011/03/Baseline-Survey_layout_forPrint 12/03/2011.pdf/ accessed on 15/ April / 2020

Retrieved from URL:

https://unctad.org/en/Docs/ecn16/1997/9_en.pdf/ accessed on $24 / J u n e / 2020$

Retrieved from URL: http://hdr.undp.org/en/countries/profiles/IND/ accessed on $01 / 09 / 2020$
Retrieved from URL: http://mospi.nic.in/sites/default/files/publication_reports/ Report_569_4dec15_1.pdf /accessed on 09/11/2020

Retrieved from URL: http://mospi.nic.in/sites/default/files/publication_reports/I ndia_in_figures-2018_rev.pdf/accessed on 31/10/2020

Retrieved from URL:

http://pib.nic.in/newsite/PrintRelease.aspx?relid=147634. en.pdf / accessed on 21/11/2020

Retrieved from URL: http://rchiips.org/NFHS 4/index.shtml/20152016/Pdf/ accessed on 25/July/2020

Retrieved from URL: http://rchiips.org/nfhs3/index.shtml/20052006/ accessed on 3/August/2020

Retrieved from URL: http://sdg.uno.org/en/composite/2015/ accessed on $01 / 07 / 2020$

Retrieved from URL: http://www.oecd.org/social/genderdevelopment/47561694.pdf / accessed on 15/11/2020

Retrieved from URL:

http://www.un.org/womenwatch/daw/egm/ict2002/report s/Paper/2020 Sonia/20/Jorge.pdf/ accessed on 11/August/2020.

Retrieved from URL: https://labour.gov.in/sites/default/files/Report/20vol/204/ 20final.pdf/ accessed on 05/10/2020

Retrieved from URL: https://unctad.org/meetings/en/SessionalDocuments/ciem 8d2_en.pdf/ accessed on 20/10/2020

Retrieved from URL: https://vvgnli.gov.in/research/centregender-and-labour-studies/ accessed on 21/09/2020

Retrieved from URL: https://www.un.org/womenwatch/daw/ict2002/reports/E GMFinalReport.pdf/ accessed on 01/July/2020

Retrieved from URL: www.unwomen.org/digitallibrary/publications/2010/6/annual-report-2017-2018/ Pdf. accessed on 15/Dec/2019.

Satyavrat SR (2017) Social and household Women Empowerment Index in India. I.J.A.R.I.I.E. 3.

Wiklander J (2010) Determinants of Women's Empowerment in Rural India, lup.lub.lu.se/student-papers, Vol.18. 